\title{
Role Of Debt Level In Mediating Effect Between Firm Size On Firm Value (Empirical Study Of Companies Listed On LQ 45 Indonesia Stock Exchange)
}

\author{
Elwisam \\ \{elwisam@civitas.unas.ac.id\},National University, Jakarta, Indonesia
}

\section{Nurseha}

\{noermuhammad01@gmail.com\},National University, Jakarta, Indonesia.

\section{Cepi Pahlevi}

\{cepipahlevi@gmail.com\}, Faculty of Economics and Business, Hasanuddin University, Makassar, Indonesia.

\author{
Andi Reni \\ \{andirenireni@gmail.com\}, Faculty of Economics and Business, Hasanuddin University, Makassar, Indonesia.
}

\author{
Mursalim Nohong \\ \{mursalim1906nohong@gmail.com\},Faculty of Economics and Business, Hasanuddin University, Makassar, Indonesia.
}

\begin{abstract}
The purpose ofstudy is to analyze howinfluence of firm size on firm value withlevel of debt as a mediating variable.sample consisted of 26 companies listed on LQ45 index 2014-2016.study uses Structural Equation Modelling (SEM) withhelp of AMOS 21 software.results showed: (1) firm size had a negative and significant effect on firm value; and (2)level of debt is proven to be able to mediate (partial mediating)relationship between company size and firm value.
\end{abstract}

Keywords:

Firm Size, Debt Level and Firm Value.

Article Received: 18 October 2020, Revised: 3 November 2020, Accepted: 24 December 2020

\section{Introduction}

Research on firm value is an important part of decision-making in corporate finance. Tight business competition forces each company to maximize level of profit can create good company value and shareholder wealth, thereby encouraging investor interest to invest funds and creditor trust to lend funds.

The value of company shows amount must be spent by buyer if company is sold Husnan and Pudjiastuti, [1]. One variable can affect firm value is firm size, Sari and Priyadi [2] and Sholichah and Andayani [3] show firm size has a positive and significant influence on firm value, where large-sized companies tend to have high company values because they are in more stable conditions and have achieved maturity stage in its life cycle, so it tends to be expected to have better and more stable prospects in the future. However, Rusiah, et al. [4] proved firm size had a negative and significant effect on firm value, while Rumondor, et al. [5] and Dewi and Sudiartha [6] actually prove firm size has no influence on firm value.

Large companies tend to be easy to access financial markets and capital markets and have ability to pay debts better than small companies. Pandey's research [7] shows tendency of increasing use of debt as company grows. Companies with a larger size, have greater confidence in getting funding sources so it will make it easier to get credit from outside parties Therefore are a large company size is a positive 
signal for creditors to provide loans.

Therefore, research will bridge research controversy between firm size and firm value by including debt level variable as a mediating variable (intervening).

\section{Research Methodology}

This research was conducted on companies listed on the LQ45 index on the Indonesia Stock Exchange in the 2014-2016 period. The sample selection is carried out using the purposive sampling method, namely with the following criteria: (1) listed on the Indonesia Stock Exchange successively from 2014 to 2016; (2) consistently becoming a member of the LQ45 index in the 2014-2016 period; and (3) regularly and consistently publishes financial statements as of December 31 in the 2014-2016 period. Based on these criteria, a sample of 26 companies was obtained.

\subsection{Effect of Firm Size on Firm Value}

Firm value is an objective value given by the public to a company with the orientation of the company's survival. Wealtherly [8] suggests three main groups of assets that underlie corporate value, namely financial assets (financial capital), physical assets (tangible assets) and intangible assets. In estimating the value of a company, Keown, et al.[9] put forward the following quantitative variables to be used. a) Book value, which is the value of assets reported in the company's balance sheet. b) Liquidity value, i.e. the amount of money that can be realized from the sale of an individual company's assets. c) Value of the market price, i.e. the value of an asset on the market-determined by demand and supply in the market itself.

Measurement of firm value can be done with several ratio approaches. One of them is the Price to Book Value (PBV) ratio approach which compares the price of shares per sheet with the book value per share. The PBV ratio measures the value given by financial markets to growing companies. This ratio shows the company's ability to form a share price from the capital it has
(Brigham and Houston) [10].

The size of the firm measures the size of assets owned by the company and the magnitude of the company's inventory turnover. Large companies will have large market capitalization, large book values, and high profits, while small companies will have small market capitalization, small book values and low profits (Fareed, et al.) [11].

The measurement of firm size uses total assets. According to Pantow et al. [12] company size is measured by transforming the total assets of the company into natural logarithms. The firm size proxies by using Natural Log Total Assets in order to reduce excess data fluctuations. By using a natural $\log$, the number of assets with a value of hundreds of billions or even trillions will be simplified, without changing the proportion of the actual amount of assets.

Large companies tend to be in a more stable condition than small or medium-sized companies because they have usually reached the stage of maturity in their life cycle, so they tend to be expected to have better and stable prospects in the future. This will increase the value of the company in public. In addition, the liquidity of large-sized companies tends to be higher because they have assets that tend to be more numerous, including current assets. This will reduce the risk of company insolvency so that the credibility and value of the company in the eyes of investors and creditors will also increase.

$\mathrm{H}_{1}$ Firm size has a positive and significant effect on firm value.

\subsection{Effect of Firm Size on Firm Value through Debt Levels}

Modigliani and Miller [13] who developed the Trade-off theory of capital structure, showed that debt is beneficial because interest can be deducted in calculating taxes, but debt also incurs costs that lead to actual and potential bankruptcy. The optimal capital structure is achieved when there is a balance between the benefits of using debt and the cost of using debt. Companies balance the benefits of funding with debt 
(favorable corporate tax treatment) with higher interest rates and bankruptcy costs.

Large companies tend to be easy to access financial markets and capital markets and have the ability to pay debts better than small companies. The greater the size of the company the greater the level of debt used by the company (Pandey, [7]).

Companies with a larger size, have greater confidence in getting funding sources so that it will make it easier to get credit from outside parties. Therefore, the size of a large company is a positive signal for creditors to provide loans. Research conducted by Ramadan et al. [14] and Huang and Song [15] shows that firm size has a positive and significant effect on debt levels.

Based on the trade-off theory, debt will cause interest expense which will be a tax deduction for the company. This will increase the number of company profits (Brigham and Houston) [10]. As a result, the value of the company will also increase. The results of research conducted by Cheng and Tzeng [16] also found that companies with leverage tend to have greater corporate value than companies without leverage (unleveraged). Thus, a high level of corporate debt but followed by good management can increase profits and initial returns.

H2: Firm size has a significant effect on Firm Value through debt levels Research model:

The structural equation model used in this study is as follows.

$$
\begin{aligned}
& \text { DER }=\alpha_{1}+b_{1} \text { SIZE }+e_{1} \\
& \text { PBV }=\alpha_{2}+b_{2} \text { SIZE }+b_{3} \text { DER }+e_{2} \\
& \text { Price to Book Value (PBV) is a proxy }
\end{aligned}
$$
variable to measure the value of a firm, which is the ratio between price and book value per share.

The firm size (SIZE) will be measured using the number of assets owned by the company which will be proxied by natural logarithm of total assets.

The mediating variable used in this study is the debt level variable which is proxies by debt to equity ratio (DER) as an embodiment of the company's long-term funding decisions as measured by comparing the total debt and own capital owned by the company.

\section{Results and Discussion}

Data analysis was performed using Structural Equation Modeling (SEM) to explain the overall relationship between research variables. The statistical program used as a general approach to table analysis in this structural equation model is Analysis Moment of Structures (AMOS).

Based on the results of the normality test and the goodness of fit model test, the data used in this study proved to be normally distributed and free from multicollinearity. Estimation results describing the research objectives are presented in table 1 as follows.

Table 1. Research result

\begin{tabular}{ccccl}
\hline $\begin{array}{c}\text { Hypothe } \\
\text { sis }\end{array}$ & $\begin{array}{c}\text { Variable } \\
\text { Relationship }\end{array}$ & $\begin{array}{c}\text { coefficien } \\
\mathbf{t}\end{array}$ & P-Value & \multicolumn{1}{c}{ Keterangan } \\
1 & SIZE --> PBV & $-0,139$ & 0,000 & $\begin{array}{l}\text { Negative and } \\
\text { significant }\end{array}$ \\
& SIZE --> DER & 0,287 & $0,000 \begin{array}{l}\text { Positive and } \\
\text { significant }\end{array}$ \\
& DER --> PBV & 0,099 & $0,036 \begin{array}{l}\text { Positive and } \\
\text { significant }\end{array}$ \\
2 & SIZE --> DER --> & & $\begin{array}{l}\text { Negative and } \\
\text { significant, } \\
\text { withlevel of debt }\end{array}$ \\
\hline
\end{tabular}


(DER) acting as

partial mediator

Based on table 1 above, the structural equation obtained from this study.

$\mathrm{DER}=0,287 \mathrm{SIZE}$

PBV $=-0,139$ SIZE $+0,099$ DER

The estimation results of direct and indirect effects are presented in the following figure.

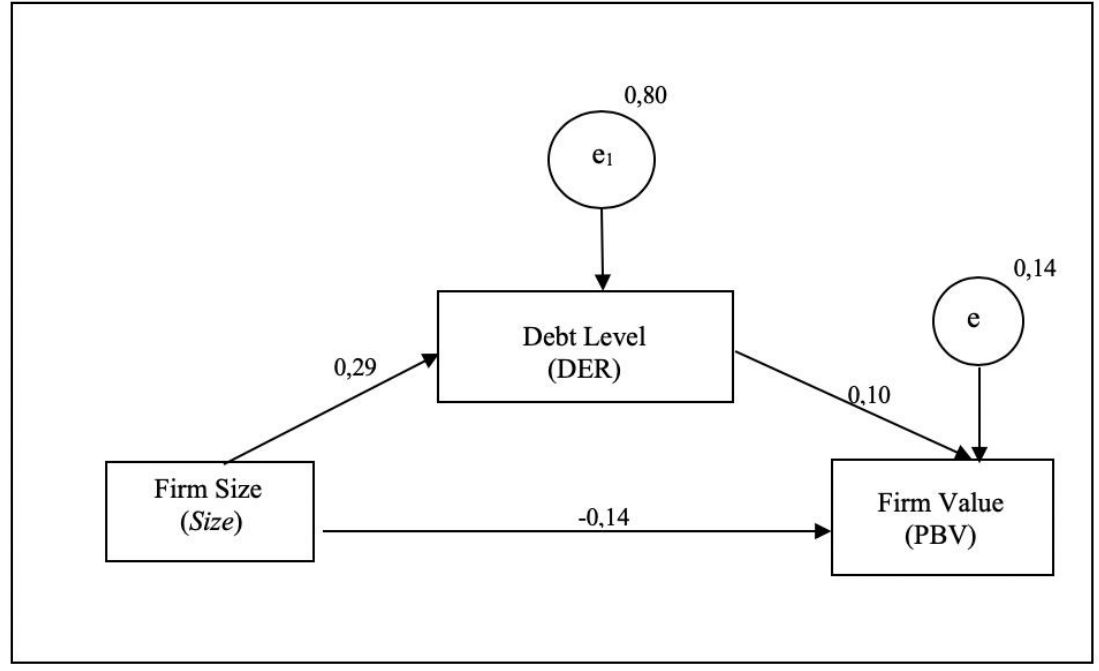

Fig. 1: The estimation results of direct and indirect effects

\subsection{Effect of Firm Size on Firm Value}

The results of this study indicate that company size has a negative and significant effect on firm value, so the larger the size of a company, the lower the value of the company. Conversely, the smaller the size of a company, the higher the value of the company. This is in line with the results of research conducted by Rusiah, et al. [4]. The results of research conducted by Rumondor, et al. [5] also proves that firm size tends to have a negative effect on firm value, but the effect size is not significant.

The size of the company itself is reflected by the number of assets owned by a company so that large companies can be interpreted as companies that have many assets. In financing the procurement and / or purchase of these assets, companies need capital, both in the form of own capital and foreign capital. In this case, foreign capital acts as a source of funds if the capital owned by the company concerned has not been able to meet the needs of its assets. Based on this, the number of assets owned by a company can reflect the amount of foreign capital used by the company to finance the procurement and / or purchase of the assets concerned, so that the larger the size of a company, the more assets owned by the company and the more there are also many debts borne by the company. The use of foreign capital in the form of debt to finance the procurement and/or purchase of these assets will increase the risk borne by the company so that it will increase fluctuations in the company's prospects in the future and reduce the level of investor interest and confidence in the company concerned. As a result, the company's stock price will decline, so that the credibility and value of the company in public will also decline.

\subsection{The Role of Debt Level in Mediating the Relationship between Firm Size (SIZE) and Firm Value (PBV)}

Table 1 above shows that firm size has a positive and significant effect on the level of debt, so the larger the size of a company, the greater the 
level of debt. This is in line with the results of research conducted by Wiagustini and Pertamawati [17] and Setyawan, et al. [18].

Meanwhile, the level of debt has a positive and significant effect on the value of the firm, so the greater the level of debt, the greater the value of the firm. This is in line with the results of research conducted by Hermuningsih [19] and Rumondor, et al. [5].

The results of this study prove that the level of debt can mediate the relationship between firm size and firm value. In this case, the effect of firm size on firm value mediated by debt levels tends to be negative. This shows that the larger the size of a company, the greater the debt level of the company, so the lower the value of the firm. Conversely, the smaller the size of a company, the smaller the debt level of the company, so the higher the value of the firm. This logically supports the results of research conducted by Rusiah, et al. [4] which shows that firm size has a direct and significant negative effect on firm value. The results of research conducted by Hermuningsih [19] and Kosimpang, et al. [20] has also proven that the level of debt can mediate the relationship between firm size and firm value. However, the relationship of influence evidenced in the two studies tends to be positive.

\section{Conclusion}

Based on the results of this study, it can be concluded that company size has a negative and significant effect on firm value, and capital structure can mediate the relationship between firm size and firm value.

The negative influence of company size on the value of the company both directly and indirectly through the level of debt, the company should take careful consideration before making a decision regarding the purchase of assets, so that the assets purchased by the company really are assets that are needed to improve its performance. The company should also control its assets to a certain reasonable extent to minimize and/or avoid inefficiencies in asset management and minimize the risk of default on the long-term debt incurred to fund the purchase and/or procurement of these assets.

The results of this study have provided some insight into the role of debt level in mediating the effect of firm size on firm value in companies listed on LQ 45 on the Indonesia Stock Exchange. Therefore, this study can provide some useful information for future research on capital structure, company size and firm value by developing new models with new hypotheses, especially for companies in developing countries.

\section{References}

[1] Husnan, S dan E. Pudjiastuti, : DasarDasar Manajemen Keuangan. UPP STIM YPKN. Yogyakarta (2012)

[2] Sari, R.A.I dan M.P. Priyadi, : Pengaruh Leverage, Profitabilitas, Size dan Growth Opportunity terhadap Nilai Perusahaan. Jurnal Ilmu dan Riset Manajemen. 5(10): 1-17. (2016)

[3] Sholichah, W.A. dan Andayani, : Pengaruh Struktur Kepemilikan, Ukuran Perusahaan dan Leverage Terhadap Nilai Perusahaan. Jurnal Ilmu dan Riset Akuntansi. 4(10): 1-17. (2015)

[4] Rusiah, N. R.M. Mardani, dan M. Khoirul, : Pengaruh Struktur Modal, Pertumbuhan Perusahaan, Ukuran Perusahaan dan Profitabilitas terhadap Nilai Perusahaan pada Perusahaan yang Terdaftar di Bursa Efek Indonesia. E-Jurnal Riset Manajemen. (2017)

[5] Rumondor, R., M. Mangantar dan J.S.B. Sumarauw, : Pengaruh Struktur Modal, Ukuran Perusahaan dan Risiko Perusahaan terhadap Nilai Perusahaan pada Sub Sektor Plastik dan Pengemasan di BEI. Jurnal EMBA. 3(3): 159-169. (2015).

[6] Dewi, D.A.I.Y.M. dan G.M. Sudiartha. Pengaruh Profitabilitas, Ukuran Perusahaan dan Pertumbuhan Aset terhadap Struktur Modal dan Nilai Perusahaan. E-Jurnal Manajemen Unud. 6(4): 2222- 2252.

[7] Pandey, I.M., : Capital Structure and Firm Characteristics: Evidence from an 
Emerging Market. IIMA Working Paper WP 2001-10-04. (2001)

[8] Weatherly, L.A., : Human Capital: The Elusive Asset. Research Quarterly. Society for Human Resource Management. Virginia. (2003).

[9] Keown, A.J., J.D. Martin, J.W. Petty, and D.F. Scott, : Financial Management. $10^{\text {th }}$ Ed. Pearson Prentice Hall. New York. (2004).

[10] Brigham, E.F. dan J.F. Houston, : Financial of Management. $11^{\text {th }}$ ed. SouthWestern Thomson Learning. Mason. (2006).

[11] Fareed, Z., Z. Ali., F. Shahzad., M.I. Nazir., A. Ullah., : Determinant of Profitability: Evidence From Power And Energy Sector, Studia UBB Oeconomika, Vol. 61, Issue 3. (2016)

[12] Pantow, M.S.R., S. Murni, dan I. Trang.. Analisa Pertumbuhan Penjualan, Ukuran Perusahaan, Return On Asset, Dan Struktur Modal Terhadap Nilai Perusahaan Yang Tercatat Di Indeks LQ 45. Jurnal EMBA. 3 (1): 961-971. (2015).

[13] Modigliani, F \& Miller, M. H.. The Cost of Capital, Corporate Finance and The Theory of Investment. American Economic Review, XLVIII(3), 261-297. (1958)

[14] [14] Huang, S dan F. Song, : Determinants of Capital Structure: Evidence from China, China Economic Review, 17, 14 - 36. (2006).

[15] [15] Ramadan, A.H., J.J. Chen., H.A. Al-Khadash., M. Atmeh., : A Mediating Role of Debt Level on The Relationship between Determinants of Capital Structure and Firm's Financial Performance, International Research Journal of Applied Finance, 3(1) 65- 92. (2012)

[16] Cheng, M.C. dan Z.C. Tzeng, : The Effect of Leverage on Firm Value and How the Firm Financial Quality Influence on This Effect. Journal of Management. 3(2): 3053. (2011).
[17] Wiagustini, N.L.P dan N.P. Pertamawati, : Pengaruh Risiko Bisnis dan Ukuran Perusahaan pada Struktur Modal dan Nilai Perusahaan pada Perusahaan Farmasi di Bursa Efek Indonesia. Jurnal Manajemen, Strategi Bisnis dan Kewirausahaan. 9(2): 112-122. (2015).

[18] Setyawan, A.I.W., Topowijono dan N.F. Nuzula, : Pengaruh Firm Size, Growth Opportunity, Profitability, Business Risk, Effective Tax Rate, Asset Tangibility, Firm Age dan Liquidity terhadap Struktur Modal Perusahaan: Studi pada Perusahaan Sektor Property dan Real Estate yang Terdaftar di BEI Tahun 2009-2014. Jurnal Administrasi dan Bisnis. 31(1): 108-117. (2016)

[19] Hermuningsih, S., : Pengaruh Profitabilitas, Size terhadap Nilai Perusahaan dengan Struktur Modal sebagai Variabel Intervening. Jurnal Siasat Bisnis.16(2): 232-242. (2012).

[20] Kosimpang, A.D., R. Andini dan A. Oemar, : Pengaruh Profitabilitas, Ukuran Perusahaan terhadap Nilai Perusahaan dengan Variabel Struktur Modal sebagai Variabel Intervening pada Perusahaan Pertambangan yang Terdaftar di BEI Periode Tahun 2012-2016. Jurnal Universitas Pandanaran. (2017) 